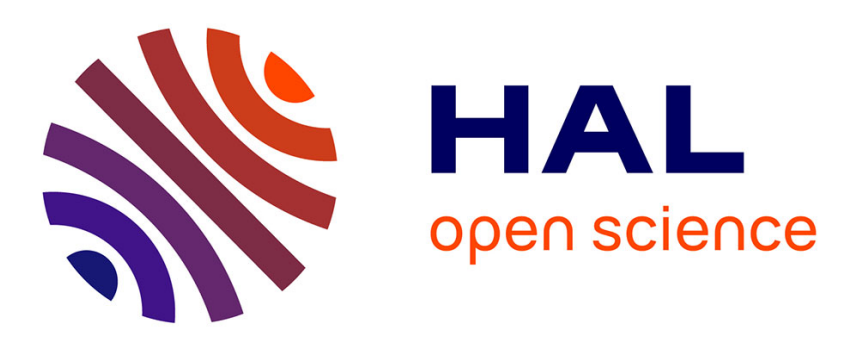

\title{
Pro-rural policies, income and inequality: Evaluating a cash-for-work program in rural China
}

Yu Chen, Sylvie Démurger

\section{To cite this version:}

Yu Chen, Sylvie Démurger. Pro-rural policies, income and inequality: Evaluating a cash-for-work program in rural China. 2014. halshs-00993574

\section{HAL Id: halshs-00993574 \\ https://shs.hal.science/halshs-00993574}

Preprint submitted on 20 May 2014

HAL is a multi-disciplinary open access archive for the deposit and dissemination of scientific research documents, whether they are published or not. The documents may come from teaching and research institutions in France or abroad, or from public or private research centers.
L'archive ouverte pluridisciplinaire HAL, est destinée au dépôt et à la diffusion de documents scientifiques de niveau recherche, publiés ou non, émanant des établissements d'enseignement et de recherche français ou étrangers, des laboratoires publics ou privés. 
Pro-rural policies, income and inequality: Evaluating a cash-for-work program in rural China

Yu Chen, Sylvie Démurger

May 2014 


\section{GATE Groupe d'Analyse et de Théorie Économique Lyon-St Étienne}

93, chemin des Mouilles 69130 Ecully - France

Tel. +33 (0)4 72866060

Fax $+33(0) 472866090$

6, rue Basse des Rives 42023 Saint-Etienne cedex 02 - France

Tel. +33(0)4 77421960

Fax. +33 (0)4 77421950

Messagerie électronique / Email : gate@gate.cnrs.fr

Téléchargement / Download : http://www.gate.cnrs.fr - Publications / Working Papers 


\title{
Pro-rural policies, income and inequality: Evaluating a cash-for-work program in rural China ${ }^{*}$
}

\author{
Yu Chen \\ University of Macau, Av. Padre Tomás Pereira, Macao SAR, China \\ E-mail: yuchen@umac.mo
}

Sylvie Démurger

Université de Lyon, Lyon, F-69003, France

CNRS, GATE Lyon Saint-Etienne, 93 Chemin des Mouilles, Ecully, F-69130, France

IZA, Bonn, Germany

E-mail: demurger@gate.cnrs.fr

\begin{abstract}
:
Despite the dramatic reduction of poverty in China over the past thirty-five years, poverty has not been fully eradicated in rural areas, and in the context of growing inequalities, it remains a national concern. This paper examines a local cash-for-work program launched in mountainous areas of Beijing municipality in December 2004, with a view to understanding both the challenges and achievements of pro-poor programs in China. Using original household survey data, we first highlight the fairly good targeting performance of the program towards the local poor. Second, participation equations provide evidence of increasing local income without crowding out local agricultural activities. Finally, a decomposition of household income inequality by source highlights the strongly equalizing effect of the program on peasants' income.
\end{abstract}

Keywords: cash-for-work program; income source diversification; agricultural households; income inequality; China.

JEL Classification: D31; O13; O15; O53.

\footnotetext{
* This paper is part of a research program funded by the Rhône-Alpes Regional Council on "Biodiversity conservation, rural ecology and rural population well-being in China". The household survey has been carried out by Sylvie Démurger in collaboration with the Beijing University of Forestry. Sylvie Démurger wishes to thank Junqing Li and Weiyong Yang as well as students from the Beijing University of Forestry for precious collaboration in conducting the survey. Yu Chen acknowledges the financial support of the University of Macau (MYRG029-FSH13-CY). We would like to thank Fredrik Sjöholm, Jinghai Zheng and participants at the 2013 Asian Economic Panel meeting at University College Dublin for valuable comments and suggestions.
} 


\section{Introduction}

One of the United Nations Millennium Development Goals (MDG) is to halve the incidence of global poverty by 2015 (UNDP, 2003). How to design policies that can help achieve this goal poses a major policy challenge to governments in developing countries where the poor devote most of their time and energy on searching for survival means and are trapped in situations where there is no hope for them to break away. In-kind and cash transfer programs are widely used to help the poor move out of the poverty trap. Typical tools include unconditional cash transfers (UCTs), conditional cash transfers (CCTs), and cash or food for work. Cash-for-work (CFW) programs are aimed at creating income generating activities among local poor households by providing them with temporary employment opportunities, mostly through infrastructure building or local resources protection. In a similar vein, foodfor-work (FFW) programs consist of paying the poor with food, in exchange for work on local public infrastructure projects or learning new skills or new agricultural methods.

Several issues are central to the evaluation of CFW or FFW programs in terms of household income and livelihood patterns. They include targeting people most in need, evaluating potential disincentive effects on agricultural activities, and assessing their overall impact on income inequality. From a theoretical perspective, there are a number of expected benefits for recipients of CFW or FFW. Beyond increased food consumption and the improvement of productivity through better local infrastructure, such transfers can also contribute to reducing the liquidity constraints that rural households often face in the context of developing countries where credit and insurance markets are largely imperfect or missing (Bezu and Holden, 2008). However, it has also been argued that these expected benefits could be counterbalanced by distortions brought by CFW or FFW to local labour markets through inflated wages or unsustainable shifts in the labour force towards non-vital activities 
(Abdulai et al., 2005), and to agricultural production through reduced investment in productive assets (Bezu and Holden, 2008).

A number of papers have empirically assessed CFW or FFW programs in the context of African countries or India ${ }^{1}$. Most show that their targeting performance has not been entirely satisfactory and stress the need for better design and implementation of the programs. Using a nationally representative survey of 4,166 farm households in Ethiopia, Clay et al. (1999) find no significant association between household food insecurity and food aid receipts, even after controlling for other characteristics of the households. In a similar vein, Jayne et al. (2002) find a significant inverse association between mean per capita income and the probability of receiving free food or food-for-work in Ethiopia, a result they interpret as illustrating a degree of inertia in food aid distribution over time. In the Indian State of Andhra Pradesh, Deshingkar et al. (2005) document different ways in which design faults, administrative mismanagement, and local corruption excluded very poor and lower caste people from participating in a FFW program.

As to whether CFW or FFW programs have disincentive effects on agricultural labour and investment, there is considerable evidence supporting that they do not. In rural Kenya, Bezuneh et al. (1988) show that FFW transfers allow peasants to accumulate more capital, which increases the opportunity cost of their time, and therefore encourages a shift over time from FFW towards own farm production. In the same area, Barrett et al. (2001) confirm that FFW significantly reduced liquidity constraints for poorer recipient households, enabling them to pursue more lucrative farm and non-farm activities and to increase both crop income and non-farm income. In the Tigray region in Ethiopia, Bezu and Holden (2008) find a positive impact of FFW on the adoption of fertilizer and no production disincentive effect.

\footnotetext{
${ }^{1}$ See for instance Andersson et al. (2011), Bezu and Holden (2008), Bezuneh et al. (1998), Clay et al. (1999), Deshingkar et al. (2005) or Jayne et al. (2001, 2002).
} 
Andersson et al. (2011) also find no evidence that participation in the Ethiopian Productive Safety Net Program (PSNP) induces rural households to disinvest in livestock or trees.

China provides ground for an interesting case study in the assessment of pro-poor policies. With an average real GDP growth rate of 9.8 percent over 1978-2012, the Chinese economy has grown at an unprecedented pace in recent decades. Multiplying per capita real GDP by 17.2, this sustained growth has contributed to a strong increase in income and a sharp reduction in absolute poverty. Hence, according to the World Bank, China has reduced its population living under the extreme poverty line of $\$ 1.25$ per day (at 2005 purchasing power parity price) from 43 percent of the world's total poor population in 1981 to 13 percent in 2010 (Olinto et al., 2013). However, the unequal distribution of the benefits of growth and the persistence of poverty in rural areas remain critical, notwithstanding impressive achievements in poverty reduction (Glauben et al., 2012; Ravallion and Chen, 2007). At the end of 2012, the number of people living under the official China poverty line (at 2,300 yuan (\$361) annual net income in 2010 prices) was close to 99 million (NBS, 2013). Recognizing the major challenges of persistent poverty and increasing inequality between rural and urban areas, Chinese policymakers have devoted more efforts and resources from the mid-2000s to helping the very poor in the countryside through a series of pro-rural policy initiatives, more generally embedded into the development goal of establishing a "harmonious society". These policies, which mark an important turning point in the development strategy of the Chinese government, include the reform of the rural taxation and fiscal system (with the complete abolition of agricultural taxes in 2006), social safety net transfers (e.g. the "New Rural Cooperative Medical Insurance System”, the "New Rural Public Pension Program”, the minimum income guarantee (dibao) system and other social relief) and a range of agricultural 
subsidies coupled with pro-environmental policies (including the Sloping Land Conversion Program [SLCP] launched nationwide in $2000^{2}$ ).

This paper presents a case study that focuses on a CFW policy implemented in mountainous areas of Beijing municipality from 2004 onwards. The policy is part of a local Forest Eco-Compensation Fund (FECF) called "Compensation Mechanism for Ecological Forests in Beijing's Mountain Area" (Nolte, 2008). As a number of other natural resource protection initiatives taken by the Chinese government during the 2000s, the ultimate objective of the policy is to achieve a win-win situation in terms of environmental protection and poverty alleviation. The CFW scheme under study consists of employing local peasants (with a fixed monthly remuneration) for protecting the village forest against fire, pest or unauthorized logging. Although the area under study has been lifted out of extreme poverty, the average income remains low and there is room for in-kind and cash transfers to help increase peasants' income in the area. The questions of interest in analysing the program effectiveness in its pro-poor objectives are: i) What are the drivers of program participation?; ii) Does the program have any disincentive effect on agricultural activities?; and iii) To what extent does the program help increase income for the participants, and to what extent has it changed the overall inequality level and its composition in the participating villages?

Using data drawn from a household survey conducted in participating villages, this paper contributes to a better understanding of pro-poor programs challenges and short-run achievements through the case study of a local small-scale program. The econometric estimation of participation equations at the household and the individual levels indicates a fairly good targeting performance of the program towards the local poor and those with limited alternative income-generating opportunities. It also provides evidence of increasing

\footnotetext{
${ }^{2}$ China's Sloping land conversion program is the largest land retirement program in the developing world. It has the dual aim of reducing soil erosion by returning crop land on steep slopes to forest or grassland, and restructuring the rural economy through a compensation scheme. The outcomes of the program have been discussed in a voluminous literature. See for instance Yin et al. (2010).
} 
local income without crowding out local agricultural activities. Last, a decomposition of household income inequality by source highlights the strongly equalizing effect of the program on peasants' income.

The rest of the paper is organized as follows. Section 2 gives a brief account of the rural poverty issue in China and introduces the Compensation Mechanism for Ecological Forests in Beijing's Mountain Area. Section 3 presents the data. Section 4 uses descriptive analysis and multivariate analysis to examine the program participation at the household and individual levels. Section 5 assesses the distributional impact of the program. Section 6 concludes.

\section{Rural poverty and pro-poor policies in China}

\section{1. Rural poverty in China}

“Looking back to 1981, China's incidence of poverty (measured by the percentage below $\$ 1.25$ per day) was roughly twice that for the rest of the developing world; by the mid1990s, the Chinese poverty rate had fallen well below average.” This quote from Chen and Ravallion (2010, p. 1602) illustrates the dramatic reduction of poverty in China, which has made it possible for the country to achieve the MDG of reducing by half the number of its people living in extreme poverty far earlier than the specified 2015 deadline. Yet, despite the undeniable and spectacular achievement of China in terms of poverty reduction, poverty has not been fully eradicated, and in the context of growing inequalities, it remains a national concern. Because poverty is largely a rural phenomenon, rural policies are key instruments in the fight against poverty in lagging regions, as reflected by the eleven consecutive "No. 1 Central Documents" issued jointly by the Central Committee of the Communist Party of 
China and the State Council that have been dedicated to rural issues between 2004 and 2014 (Xinhua News Agency, 2014) $)^{3}$.

As stressed in the literature, the pattern of poverty reduction in China has not been smooth. Starting with an estimated number of rural people living in extreme poverty at 250 million in $1978^{4}$ (Glauben et al., 2012), China has experienced a rapid decline in poverty in the first half of the 1980s. The implementation of the household responsibility system (HRS) and the development of rural industries through township and village enterprises (TVEs) successfully spurred rural economic growth across the nation and contributed to rural income growth in the 1980s (Lin, 1992; Weitzman and Xu, 1994). However, as the economic reform focus shifted to cities after 1984, urban areas became the main beneficiaries of the rapid economic growth, and from the late 1980s, rural income growth slowed down and poverty reduction stagnated (Chen and Wang, 2001; Ravallion and Chen, 2007). In the mid-1990s, rural China experienced a second episode of sharp poverty reduction thanks to significant increases in the procurement prices of agricultural products (Imai and You, 2013). However, the urban-rural gap continued to widen, leading the $16^{\text {th }}$ National Congress of the Communist Party in 2002 to set the increase of rural households' income as the main goal for the next decade and the move of labour out of farming as a way of achieving this goal (Dong et al., 2010). Building a "harmonious society" based on more balanced growth between rural and urban areas became a popular slogan and in March 2006, the National People's Congress approved the intention to "build a new socialist countryside" as a government policy. The main measures in favour of the rural sector issued throughout the 2000s included the abolishment of agricultural taxes and levies, public investment in infrastructure, easing restrictions on rural-to-urban migration, the implementation of nine-year free compulsory

\footnotetext{
${ }^{3}$ Interestingly, key measures in the reform of rural areas at the beginning of the 1980s were also issued through five consecutive No. 1 Central Documents between 1982 and 1986, reflecting the priority placed on the rural sector at the very beginning of the reform process (OECD, 2009).

${ }^{4}$ This estimation is based on a national poverty line set as an annual food grain consumption of less than 200 kilograms per capita.
} 
education, and the development of a rural safety net programs such as medical and pension systems (Dong et al., 2010). For the 2000s, the available evidence finds a substantial decrease in the rural poverty rate, but an increase in extreme poverty for the remaining poor (Luo and Sicular, 2013).

Since the early 1980s, the Chinese government has been committed to formulating and implementing poverty reduction policies that can be broadly classified into five phases (Table 1). From 1978 to 1985, the leadership encouraged rural reforms, which boosted agricultural production and enabled a large share of rural households to attain food security and get out of poverty. In 1986, after the immediate benefits of rural reforms faded away, the Chinese government initiated a nationwide poverty alleviation strategy and established the Leading Group for Economic Development in Poor Areas (renamed the State Council Leading Group of Poverty Alleviation and Development in December 1993) to supervise and monitor the implementation of a range of antipoverty initiatives. As highlighted by Meng (2013), the novelty of the strategy was that poverty targeting was based on officially designated poor counties ${ }^{5}$ and the emphasis was put on the promotion of revenue-generating activities, and more generally economic development. Part of the strategy relied on the creation of special funds for subsidized loans, FFW and budgetary grants to poor areas. Despite the various programs offered, the growth of agricultural productivity came to a halt from the mid-1980s and poverty reduction stagnated for years.

In 1994, the central government unveiled a new antipoverty program called the " $8-7$ plan" with the objective of lifting the remaining 80 million rural poor out of poverty within seven years (1994-2000). The new plan was actually meant to intensify the existing policies. Covering 592 counties, it maintained the three main channels for poverty reduction through subsidized loans for investment in production and economic development, FFW to build rural

\footnotetext{
${ }^{5}$ The designation of poor counties was done according to a mixed set of poverty lines. In 1986, 258 counties were designated as poor; the number increased to 328 in 1988. See Park et al. (2002) for a description of the designation process and an account on the complaints surrounding the program placement.
} 
infrastructure, and government budgetary grants. Using a regression discontinuity design, Meng (2013) estimates that the 8-7 Plan produced a sizeable positive impact on rural income growth.

At the turn of the century, the government took a new step in its antipoverty strategy by launching the New Century Rural Poverty Alleviation Plan for 2001-10. The major innovation of this plan was to switch from an area-based poverty reduction policy to peoplecentred approaches, keeping the same transfer tools as in previous programs. In particular, the new plan took into account the fact that in western regions, poor households are scattered in poor villages rather than concentrated in poor counties. Hence, in addition to poor counties, it targeted 50,000 poor villages, with the aim of reaching poor villages in non-poor counties excluded from previous programs.

The latest phase in the country's effort to eradicate poverty started in 2011, when China issued a new policy outline for poverty alleviation ("Outline for Poverty Reduction and Development of China's Rural Areas (2011-2020)") over the next 10 years. Apart from the emphasis on the need to improve infrastructure and public services, the major change brought by this new policy outline was the lift in the poverty line from 1,196 yuan to 2,300 yuan per year and the authorization given to provinces and autonomous regions to "set their own poverty line in accordance with local average incomes, natural conditions and other circumstances" 6 . The change is significant in that it signals the official recognition of the necessity to include more people in government funded social support schemes ${ }^{7}$. And indeed, with the new poverty line, 128 million people were made eligible for anti-poverty subsidies in 2011, a 100 million jump compared to the officially counted rural poor in 2010 .

\footnotetext{
6 "Govt to let regions establish their own poverty standards", China Daily, August 18, 2011. http://www.chinadaily.com.cn/cndy/2011-08/18/content 13138347.htm. Accessed February 17, 2014. ${ }^{7}$ The poverty line has been adjusted a number of times during the last 30 years. From 206 yuan in 1986, it had reached 1,274 yuan in 2010 through a succession of adjustments, mostly meant to follow inflation.
} 
The main tools for rural poverty reduction that have been put forward with a different intensity over time include the four pathways highlighted by Christiaensen et al. (2013): improvements in agricultural productivity, rural nonfarm diversification, migration and transfers. During the 1980s, an important development that has helped boost the rural economy has been the growth of rural industries in the countryside, providing job opportunities to millions of peasants who were restricted to move to cities by the household registration system (hukou). As market reforms proceeded and the household registration system became less stringent than before, rural-to-urban migration has become an increasingly more feasible way for reducing poverty in the countryside. Du et al. (2005) find that having a migrant increases a household's income per capita by 8.5 to 13.1 percent. However, the overall impact of migration on poverty reduction is modest because most poor people do not migrate (Du et al., 2005). Helping to improve income and living conditions for those staying in the countryside remains a daunting issue and alternative solutions need to be found and implemented. This is what this paper is about: the program under study provides an interesting case study of a local small-scale initiative that offers alternative local sources of income to peasants.

\section{2 The Beijing Forest Eco-Compensation Fund}

It is in the context of the pro-rural orientation of policies that the municipality of Beijing promulgated in August 2004 a "Notice on the Establishment of a Compensation Mechanism for Collective Ecological Forests in the Mountainous Regions of the Municipality of Beijing". The proposed compensation scheme is motivated by environmental as well as economic reasons. On the environmental side, the municipality of Beijing is located in an ecologically fragile and vulnerable area, which suffers from chronic water shortages (particularly fuelled by a prolonged dry spell between 1999 and 2007), water 
pollution, and low forest quality and ecological functions. About two-third of the municipality surface is mountainous, with forest coverage of 35 percent in 2005 (Nolte 2008). On the economic side, the municipality is characterized, as many other provinces in China, by a large income gap between urban and rural areas: in 2004, the ratio of per capita disposable income in urban Beijing to per capita net income in rural Beijing was 2.5. Given its mountainous topography, the landlocked areas of the municipality have not had much opportunity to benefit from the rapid economic development of the urbanised part of the municipality.

In September 2004, the Bureau of Forestry and the Bureau of Finance of the municipality of Beijing promulgated a document, that laid out concrete measures and requirements for the implementation of the compensation mechanism, and the Beijing Forest Eco-Compensation Fund was launched in December 2004 for a period of 6 years (Nolte, 2008). The core of the compensation fund was to create forest warden jobs to protect ecological forests in Beijing's mountainous areas. By the end of 2006, about 46,000 jobs of forest wardens had been created across villages in the municipality, accounting for 20 percent of the 230,000 total rural surplus labour force of the area (Gao et al. 2008), and about 640,000 hectares of ecological forests were managed through the program.

The budget comes primarily from the municipality, and is distributed annually by the town and township financial departments to the villages under their jurisdiction. Forest wardens are responsible for forest tending, pest control and preventing forest fires or illegal logging. Their main task is then to watch over the use of fire in the open air and to control logging. In practice, they mostly supervise the neighbourhoods of the village, without going deeply into the forest. The targeted population for the job are peasants, preferably those with low income. Village cadres and villagers engaged in industry or services with secure off-farm income are explicitly made non eligible (Nolte, 2008). There is no special skill requirement for applying 
for the job, except for old people (if less mobile). A rotation among inhabitants or households every year is also allowed to favour intra-village redistribution. The monthly salary per person was initially suggested at RMB400, with the possibility for adjusting the rules and the level of wages to be paid to forest wardens at the village level. For equal distribution purposes, for example, some villages in our study site have decided to increase the number of wardens recruited at a lower salary.

Given its design, the program falls into the category of a cash-for-work program (Andersson et al. 2011): local people are employed in public work (3 days a week) and the major economic objectives of the program are to smooth peasants' income and improve the living conditions of local households, while at the same time contributing to a public good -forest protection here. By doing so, the program also aims at creating awareness on the importance of sustainable forests among the village community, encouraging villagers to protect their forest, and more generally changing their attitudes towards forests.

\section{Study site and data}

The survey site is in Labagoumen township, which is located in Huairou district in the municipality of Beijing. The township constitutes the northernmost group of villages in the municipality on the Hebei border, with a population of about 7,000 inhabitants. Surrounded by high and steep forested mountains, it is characterized by a rough topography and unfavourable weather conditions. Forest land represents 83 percent of total land whereas arable land only accounts for 3 percent. As a consequence, the population pressure upon land is severe and the average farm size is less than 0.5 hectare per household. In economic terms, the area is poor compared to both neighbouring townships and provinces (Démurger et al., 2010). Until recently, the agricultural sector alone employed most of the active population, 
and the township relied heavily on subsistence agriculture and the production of corn for seed. However, being located upstream of the Miyun reservoir (Beijing municipality's most important source of drinking water), the area has been targeted by several ecological protection policies before the implementation of the Beijing forest eco-compensation fund, which have also impacted the local economic structure. In particular, the establishment of a municipal-level nature reserve in 1999 enhanced its tourist appeal, thus promoting the development of tourism-related activities in some villages (Démurger et al. 2010; Démurger and Fournier 2011). Moreover, from 2001 onwards, the implementation of the nationwide SLCP in the township contributed to the conversion of agricultural land into forested land and a progressive reduction of purely agricultural activities.

The data used are drawn from a household survey carried out in March 2009 within a larger project designed to analyse the welfare impact of various ecological protection policies in the township. Ten administrative villages have been chosen so as to be fairly representative of the geographical and economic conditions of the township. The area is served by two main roads: the national highway 111 (that links Beijing city to Heilongjiang province) and a secondary road that runs to the entrance of the nature reserve in Sunzhazi village. Among the 10 villages surveyed, 4 are located along the national highway, 3 are located along the (only) secondary road and the other 3 are remote villages with no direct access to the national highway. In each village, about 30 to 35 households were randomly selected and interviewed on a face-to-face basis by enumerators from Beijing Forestry University. A total of 321 households were interviewed, with 233 households engaged in the forest eco-compensation program. Households were given a (30 yuan value) gift in compensation for the time they spent with the survey team. The survey provides a series of information about both family and individual members. Household information includes farm and non-farm activities, income by source, durable goods and asset holdings. 
As described above, the Beijing forest eco-compensation fund policy has been implemented in a decentralized manner and each village was basically free to set its own rules to allocate the forest warden jobs. Table 2 shows inter-village differences in program participation and in income by source. It highlights substantial heterogeneity across villages both in the share of households involved in the program (from 16.7 to 91.4 percent) and in the share of income that the program brings to villagers (from 7.1 to 55 percent). Villages can be grouped depending on main income sources and their share in total household income. A first group is made of villages where the share of agricultural income in total income remains relatively high (between 22 and 37 percent) and the share of other income sources (including subsidies) is above 20 percent, whereas the share of off-farm income is lower than 50 percent. These villages can be characterized as agricultural villages where government subsidies make a non-negligible source of income. A second group is composed of villages where off-farm income accounts for about three-quarters of total income, whereas the agricultural activity provides a much smaller share of income and other sources of income are negligible. This group typically includes villages that have sent many young people to migrate and that are also strongly involved in the forest warden program. The third group is composed of villages with very little income from agriculture, either because they have sent migrants to cities or because they have converted most of their agricultural land from which they receive governmental compensation through the Sloping land conversion program. 


\section{Identifying recipient households and participating individuals}

We start by identifying program recipient households. For this purpose, we proceed in two steps. We first report summary statistics for participating and non-participating households. We then use a Probit participation model to investigate the key drivers of participation in the forest warden program at both the household and village levels.

Table 3 shows summary statistics for the whole sample as well as comparisons between participating households and non-participating households. In terms of raw statistics, participating and non-participating households mostly differ in household composition and labour force availability, while they share common characteristics in productive and nonproductive assets. Hence, households in both groups do not significantly differ in asset holdings, measured by arable land per capita and the equipment of the dwelling with a bathroom. In contrast, they differ in household size and composition: participating households are significantly larger with more active members and fewer elderly. Similarly, participating households have significantly younger household heads and members in better (self-reported) health. All these factors indicate a better availability of working-age and healthy people in participating households for enrolling in a rather time-consuming activity.

In the second step, we use a maximum likelihood probit estimation to identify the program participation drivers at the household level. The estimated probit equation takes the following form:

$$
P_{i}=\alpha+\beta X_{i}+\gamma V_{i}+\varepsilon_{i}
$$

where $P_{i}$ equals one if at least one of the members of the household $i$ holds a forest warden job and zero otherwise. The household program participation is determined by a vector of observable household characteristics $X$, which contains households characteristics (age of household head, average household health status, ethnic minority status, and local 
political status), household composition and labour force (household size, number of active members, elderly and children below seven, a dummy for participation to the SLCP, and a dummy for having migrants in city), and household assets (arable land per adult and house equipped with a bathroom). The vector $V$ contains village fixed effects and $\varepsilon$ is the error term for the unobservable factors that may affect program participation.

Table 4 gives the marginal effects of the likelihood of households' program participation. First, household composition and assets are found to be important drivers: larger households with a larger labour force (more active members, fewer elderly members, no migrants) available for enrolling as forest wardens are more likely to participate, while wealthier households (whose dwelling is equipped with a bathroom) are less likely to participate. These results are consistent with the pro-poor objective of CFW programs: recipients households are those most in need with available labour force to enrol. This is complemented by the positive association between participation in the Sloping land conversion program and the forest warden program. Since the land retirement associated with SLCP participation mechanically reduced labour force needs for agricultural activity, SLCP participating households are more likely to have available labour force for undertaking a time-consuming activity. Interestingly, we also find that households with more arable land per adult are more likely to participate. This finding suggests that participation in the forest warden program is a complement to, rather than a substitute for, farming activities. Finally, the estimation also shows the importance of age in determining household's participation: households with younger household heads are more likely to participate in the program.

To complement the household level analysis, we turn to individual job choices and forest warden program participation. For this analysis, the sample is restricted to individuals 
aged between 16 and 75 , which roughly corresponds to the local available labour force ${ }^{8}$. Table 5 shows the distribution of individual occupations for this sub-sample. At the individual level, a person can be employed in more than one job, especially if he/she is a forest warden, which is not a full-time job by definition. Hence, figures reported in the table do not sum up exactly because some individuals actually hold more than one occupation. About two-thirds of the surveyed working-age individuals have a farming activity; slightly less than half are employed as forest wardens, and those working off the farm, either locally or as migrants, account for 11 percent and 14 percent, respectively. Finally, almost one in five individuals does not engage in any productive activity.

There is a clear correlation between farming and participation in the forest warden program: 89.6 percent of the individuals who declare being forest wardens also declare some family farming activity. Likewise, two-thirds of the farmers declared being forest wardens at the same time. Table 6 shows the correlation between occupations, and confirms the complementarity between these two activities: the correlation coefficient at 0.585 is by far the largest and is highly significant. In contrast, local off-farm activity is not significantly correlated with forest warden activity, and unsurprisingly, migration is negatively correlated with forest warden activity.

Non-parametric kernel density estimations for the age distribution by activity are presented in Figure 1. As widely documented in the empirical literature on China, rural-tourban migration is highly concentrated in the 20-30 year age group. This is also the case for our sample. Interestingly, and as a further illustration of the complementarity between forest warden activity and farming, the age distribution of forest wardens follows that of farmers, with an average age for forest wardens at 49.4 years, above the sample average (44.4). Among other demographic characteristics of forest wardens, about half are women and they

\footnotetext{
${ }^{8}$ Though the official retirement age is 55 for women and 60 for men, applying this rule to the rural economy would leave aside a share of the population that still contributes to farming or local activities, possibly including forest wardens.
} 
tend to be slightly less educated than the overall sample (aged between 16 and 75) with an average of 6.5 years of education against 7.4.

To examine the determinants of individual participation in the forest warden program, we use a multinomial logit model where any other occupation than farming and/or forest warden is the reference. Because farming and forest warden activities can be undertaken jointly, we consider separately the following three choices: joint farming and forest warden activity, forest warden job only, farming only. We test the independence of irrelevant alternatives (IIA) hypothesis with the Hausman-McFadden test based on comparing the estimated parameters with parameters obtained by excluding the alternatives one by one. The IIA hypothesis cannot be rejected at conventional levels, which allows us to use a multinomial logit model. The estimation results are reported in Table 7. The reported coefficients are exponential values that can be easily interpreted in terms of "relative risk ratios": for each variable $X$, the relative risk ratio tells us how the probability of choosing $j$ relative to the baseline alternative changes if $X$ increases by one unit.

Individual characteristics matter for program participation. Unsurprisingly, we find that program participation increases with age and decreases with the education level (as does farming). This finding might reflect some intra-household division of labour across age cohorts: younger more educated members are involved in more remunerative off-farm activities (either locally or as migrants) whereas older members remain in farming and take the cash-for-work opportunity offered through the program. Interestingly, a gender difference appears between farming and forest warden choices: whereas men tend to be significantly more into farming, they are significantly less likely to choose forest warden only. This result may be related to the fact that being a forest warden only means that the person is unemployed otherwise. The program may thus have given an opportunity to women doing only housework to derive some additional income for the family. Finally, whereas minority 
people are significantly more likely to engage in farm work than in any other off-farm work, it is not the case for program participation (if anything, they would actually be less likely to participate). Likewise, whereas being a Party member or a village committee member strongly increases the individual likelihood of doing farming rather than off-farm work, there is no significant difference for forest warden activity. This result suggests that the program requirements about individual eligibility have been followed because local officials were not eligible.

Regarding household characteristics, the individual program participation rate seems to be more influenced by household size and composition through their impact on farming decision than directly since none of these characteristics significantly influence the forest warden only choice. Interestingly, when it comes to household assets, we find that larger arable land per adult reduces the probability to enrol as a forest warden only but unsurprisingly increases the probability to do farming, which can be complemented by being a forest warden. This finding confirms that farming and forest warden activities are complementary and that the program did not have any strong disincentive effect on farming activities.

In sum, the multivariate analyses proposed in this section give support to a fairly good correspondence between the targeting objective and the outcome of the forest warden program. At the household level, poorer households are found to be significantly more likely to participate and at the individual level, people with lower alternative opportunities (older people, less educated people and women) are found to be more likely to engage in forest warden activity. Our results also clearly indicate a complementarity between farming activities and the forest warden program, which supports the absence of any significant disincentive effect of the CFW program on local farming activities. 


\section{The distributional impact of the program}

To investigate how the Beijing forest eco-compensation fund is affecting local livelihood patterns, we now turn to an analysis of household income and income inequality. In 2008, average household income was 18,439 yuan, with a median at 12,900 yuan. In per capita terms, the corresponding figures were 5,633 yuan and 4,500 yuan. The average per capita income is 18 percent above the national per capita net income of rural residents reported by the National Bureau of Statistics of China (4,761 yuan in 2008, NBS (2009)).

A comparison of income sources between 2003 and 2008 shows huge changes in the 5-year period and clearly illustrates a changing pattern from agriculture to off-farm activities (Table 8) ${ }^{9}$. Indeed, while farm income represented more than one-third of the households' annual income in 2003 , it only accounted for 18 percent in 2008 , despite the fact that the percentage of households involved in farming was actually higher in 2008 . The drop in the farm income share was compensated by an increase in off-farm income share, which accounted for about two-thirds of the annual income in 2008. For those households with income from a specific source, it is by far the most remunerative (whatever the source). The majority of off-farm income comes from two sources: forest warden salaries (with a share of 34 percent in total average income) and migrants' remittances (15 percent).

Table 8 also highlights a few interesting changes between 2003 and 2008 regarding non-farm activities and income. First, many more households were involved in off-farm activities in 2008 compared to 2003 ( 88 percent against 52 percent). This was particularly the case for migration, the only category for which a direct comparison between 2003 and 2008 is possible. About one-third of the households received remittances from migrant members in

\footnotetext{
${ }^{9}$ Data for the year 2003 come from a household survey conducted in December 2003 by the same team (see Démurger et al. (2011) for a description of the survey). Yet, income sources in 2003 and 2008 are not fully comparable because some categories were not defined in 2003. The numbers reported in Table 8 are only those that can be consistently compared with data for the year 2008 .
} 
2008, while this share was only 12 percent in 2003. Second, the share of "other income" remains stable although the percentage of households with other income has jumped from 27 percent to 68 percent.

As far as income inequality is concerned, the Gini coefficient of household per capita income in the surveyed area was 0.372 for the year 2008, a number close to the Gini coefficient for rural China estimated by the National Bureau of Statistics of China (at 0.378 for 2008, NBS (2009)). To understand the contribution of the different sources of income to inequality, we follow the approach proposed by Lerman and Yitzhaki (1985) and decompose the Gini coefficient by income sources. As shown by Lerman and Yitzhaki (1985), the Gini coefficient for total family income inequality $G$ can be expressed as follows:

$$
G=\sum_{k=1}^{K} R_{k} G_{k} S_{k}
$$

where $k$ stands for income component, $S_{k}$ is the share of income source $k$ in total income, $G_{k}$ is the relative Gini of component $k$ (corresponding to the distribution of income from source $k$ ) and $R_{k}$ the Gini correlation between income component $k$ and total income. Thus, for any income component $k, S_{k}$ measures how important the income component is with respect to total income, $G_{k}$ indicates how (un)equally distributed the income component is, and $R_{k}$ how the income component and the distribution of total income are correlated.

Using this decomposition method, Table 9 presents the contribution of income sources to income and to income inequality. The weights of income sources $S_{k}$ displayed in column (1) show that remittances from migrants and forest warden salaries both represent the largest income shares, at respectively 26 and 23 percent, followed by farm income (15 percent), other wage work earnings (13 percent), subsidies (6 percent), family nonagricultural income (6 percent) and income from self-employment ( 5 percent). 
In terms of income distribution, column (2) shows a large variation across income sources. The most unequally distributed sources of income are, by decreasing order, income from self-employment (with a source Gini at 0.95 ), family non-agricultural income, other income, and other wage work. Remittances come fifth, and they are also strongly unequally distributed across households, with a source Gini at 0.83 . On the other hand, forest warden salaries clearly exhibit a much more equal distribution (0.50) compared to any other source of income, while agricultural income and subsidies are intermediate. However, a high source Gini does not necessarily imply that the income component has a dis-equalizing effect on total income inequality (Taylor et al. 2005). Indeed, if an income source is unequally distributed, its impact on total income inequality will ultimately depend upon which households, at which points of the income distribution, receive the income source. In our sample, this is the case for "other income", which mostly includes pensions and is an income component for only 15 percent of the households. Although the source Gini coefficient is 0.94 for other income, the Gini correlation with the distribution of total income $R_{k}$ is small $(0.36)$ and the percentage contribution of other income to inequality ( 3 percent) is smaller than their percentage contribution to income $S_{k}$ (4 percent).

Table 9 clearly highlights two important sources of income, remittances and forest warden salaries, which have opposite effects on the distribution of rural income. On one hand, remittances are not only unequally distributed, but they also have a dis-equalizing effect on total income as shown in columns (4) and (5). The Gini correlation of migrant remittances with the distribution of total income $R_{k}$ is high (0.80) and the percentage contribution of remittances to inequality is actually much larger ( 37 percent) than their percentage contribution to income $S_{k}$ (23 percent). On the other hand, the equalizing role of forest warden jobs is confirmed by the small Gini correlation with the distribution of total income 
$R_{k}(0.27)$ and the small percentage contribution of forest warden salaries to income inequality (8 percent), despite their large percentage contribution to income $S_{k}(26$ percent).

Using the Gini decomposition, we can also estimate the impact of small changes in an income source on inequality, holding income from all other sources constant (Stark et al., 1986). This is shown in the last column of Table 9. As expected, both remittances and forest warden salaries have the highest impact on inequality, one being the largest income disequalizer and the other the largest income equalizer. Hence, while a 1 percent increase in remittances would increase the Gini coefficient of total income by 0.14 percent, a 1 percent increase in forest warden salaries would reduce the Gini coefficient by a similar amount, at 0.17 percent. Interestingly, besides forest warden wages, the other income components that are income equalizer are subsidies, farm income, and to a very small extent, other income. Regarding subsidies, which partly include compensations received within the Sloping land conversion program, the Gini decomposition shows that a 1 percent increase in subsidies would reduce the Gini coefficient by 0.08 percent. Hence, compared to another ecological pro-poor program (the Sloping land conversion program), the forest warden program appears to be twice more income equalizing at the local level.

To complement the analysis, Table 10 and Table 11 display income decomposition by source for villages grouped according to the relative importance of their agricultural income. As highlighted in Section 3, there are substantial inter-village differences in program participation and in income by source (see Table 2). Hence, the decompositions aim at highlighting how the importance and the distributional impact of various income sources differ across village groups. In villages with important agricultural income (Table 10), farm income has an equalizing effect, equivalent to that of forest warden wages. A 1 percent increase in farm income reduces total income inequality by 0.07 percent, as would do a 1 percent increase in forest warden salaries. In these villages, the source Gini for forest warden 
wages is much higher, at 0.65 , than for the township as a whole whereas the Gini correlation with the distribution of total income $R_{k}$ is lower. Hence, in villages where farm income is important, the distributional impact of the Beijing forest eco-compensation fund is much less equalizing than in other villages: forest warden salaries are more unequally distributed there, but the Gini correlation is low so that the overall impact is equalizing. By contrast, in villages where agricultural income is much smaller (with an average income share of 0.11 against 0.27 for agricultural villages), forest warden wages have a strong equalizing effect: a 1 percent increase in forest warden salaries would reduce the total income Gini by 0.25 percent, which is by far the largest marginal effect identified. As far as the other income components are concerned, three additional comparisons are worth noticing. First, farm income is only an income equalizer for agricultural villages (Table 10), whereas the income component has no effect for other villages (Table 11). Second, in both groups of villages, remittances are income dis-equalizers in similar proportions (with a marginal effect of about 0.14 percent). Third, subsidies are income equalizers for all villages, but their marginal effect is almost twice as high for agricultural villages where they also account for a larger share of total income.

\section{Conclusion}

Designing effective anti-poverty strategies is among the main preoccupations of most governments in developing countries. Whether pro-poor programs can indeed achieve the goal of targeting aid to intended beneficiaries, whether they can avoid disincentive effects on agricultural activities, and whether they can help reduce income inequality are central issues to assess. This paper contributes to a better understanding of pro-poor programs achievements by assessing a local CFW program launched in mountainous areas of Beijing 
municipality in December 2004. The Beijing forest eco-compensation fund aims at both ensuring forest protection in the area and improving the living conditions of the local population. The compensation mechanism consists of employing local peasants to watch over the village forest at a fixed monthly remuneration.

Using original household survey data, we highlight a fairly large participation rate among local rural households (73 percent), in accordance with the explicitly redistributive design of the policy in most villages. The estimation of participation equations shows that, at the household level, poorer households are significantly more likely to participate, and at the individual level, people with lower alternative opportunities (older people, women, less educated people) are more likely to engage in the forest warden activity. These findings suggest a rather good targeting performance of the CFW program, which is corroborated by anecdotal evidence from the field survey, with no record of complaints from interviewed households regarding the selection of households into the program and an overall reported satisfaction towards the program.

As a supportive policy for the poor, CFW is meant to help poor households extract initial income surplus that can be used to gradually increase investment in productive activities in agriculture or in off-arm activities. Given the cross-sectional nature of our data, we cannot claim testing a causal link for our case study. However, participation equations provide evidence of a complementarity between farming activities and forest warden jobs. By bringing in new local non-farm income opportunities, the program seems to have been successful in increasing local income without crowding out local agricultural activities. The absence of any obvious disincentive effect on agricultural activities due to the program is most probably related to the nature of the forest warden job, which does not require intensive work, is rather flexible and not full-time, and can easily complement agricultural work done on neighbouring land. Finally, to complement the analysis, a decomposition of household 
income inequality by source highlights the strongly equalizing effect of the forest warden income component on peasants' income.

As a case study, the proposed analysis is informative about how local anti-poverty programs can be effectively implemented and their potential achievements. However, the external validity of such a small-scale study is typically difficult to assess. Although the area under study is poor, poverty there is typically lower than in other, remote parts of China, where access to off-farm income is also presumably lower and subsistence agriculture more prevalent. Nevertheless, it sheds light on the potential benefits that small-scale, local antipoverty programs can confer over large-scale, top-down programs. In particular, the informational advantage of local institutions enables a better targeting of beneficiaries, with an immediate distributive effect.

How can the identified achievements of the program be translated into long-lasting effects in terms of poverty reduction in the area? What the analysis shows is that in the short run, the program has brought additional income to households that contributed to equalizing the income distribution at the local level. In that respect, the Beijing forest eco-compensation fund can be considered successful. Transforming the initial surplus income into incomegenerating activities that can break the poverty spiral is an issue more demanding yet. Reaping the long-term benefits of the program clearly depends on its ability to improve local peasants' savings on the one hand, and on local opportunities available to support the development of new income-generating activities (including access to credit, access to markets, climate, etc.) on the other. 


\section{References}

Abdulai, Awudu, Christopher B. Barrett, and John Hoddinott. 2005. Does food aid really have disincentive effects? New evidence from Sub-Saharan Africa. World Development. 33(10):1689-1704.

Andersson, Camilla, Alemu Mekonnen, and Jesper Stage. 2011. Impacts of the Productive Safety Net Program in Ethiopia on livestock and tree holdings of rural households. Journal of Development Economics. 94(1):119-126.

Barrett, Christopher B., Mesfin Bezuneh, and Abdillahi Aboud. 2001. Income diversification, poverty traps and policy shocks in Cote d'Ivoire and Kenya. Food Policy. 26(4):367-384. Bezu, Sosina, and Stein Holden. 2008. Can food-for-work program encourage agricultural production? Food Policy. 33(6):541-549.

Bezuneh, Mesfin, Brady J. Deaton, and George W. Norton. 1988. Food Aid Impacts in Rural Kenya. American Journal of Agricultural Economics. 70(1):181-191.

Chen, Shaohua, and Martin Ravallion. 2010. The Developing World is Poorer than We Thought, But No Less Successful in the Fight Against Poverty. The Quarterly Journal of Economics. 125(4):1577-1625.

Chen, Shaohua, and Yan Wang. 2001. China's growth and poverty reduction: recent trends between 1990 and 1999. World Bank Policy Research Working Paper no. 2651. Washington D.C.: The World Bank.

Christiaensen, Luc, Lei Pan, Sangui Wang. 2013. Pathways out of poverty in lagging regions: evidence from rural western China. Agricultural Economics. 44(1):25-44.

Clay, Daniel C., Daniel Molla and Debebe Habtewold. 1999. Food aid targeting in Ethiopia: A study of who needs it and who gets it. Food Policy. 24(4):391-409. 
Démurger, Sylvie, Martin Fournier, and Weiyong Yang. 2010. Rural households' decisions towards income diversification: Evidence from a township in northern China. China Economic Review. 21(S1):S32-S44.

Démurger, Sylvie, and Martin Fournier. 2011. Poverty and firewood consumption: A case study of rural households in northern China. China Economic Review. 22(4):512-523.

Deshingkar, Priya, Craig Johnson, and John Farrington. 2005. State Transfers to the Poor and Back: The Case of the Food-for-Work Program in India. World Development. 33(4):575-591.

Dong, Xiao-Yuan, Paul Bowles, and Hongqin Chang. 2010. Managing Liberalization and Globalization in Rural China: Trends in Rural Labour Allocation, Income and Inequality. Global Labour Journal. 1(1):32-55.

Du, Yang, Albert Park, and Sangui Wang. 2005. Migration and rural poverty in China. Journal of Comparative Economics. 33(4):688-709.

Gao, Lan, Feng Mi, and Xiangyu Cui. 2008. Analysis of implementation results of compensation policy of non-commercial forest in Beijing's mountainous areas. In Theory and Practice of Forestry Technology and Economics, edited by Jiancheng Chen, Weiming Song, Jintao Xu, and Minghua Tian, pp. 154-165. Beijing: China Forestry Publishing House. [in Chinese].

Glauben, Thomas, Thomas Herzfeld, Scott Rozelle, and Xiaobing Wang. 2012. Persistent Poverty in Rural China: Where, Why, and How to Escape? World Development. 40(4): 784795.

Imai, Katsushi S. and Jing You. 2013. Poverty Dynamics of Households in Rural China. Oxford Bulletin of Economics and Statistics. doi: 10.1111/obes.12044. Jayne, Thomas S., John Strauss, Takashi Yamano, and Daniel Molla. 2001. Giving to the Poor? Targeting of Food Aid in Rural Ethiopia. World Development. 29(5): 887-910. 
Jayne, Thomas S., John Strauss, Takashi Yamano, and Daniel Molla. 2002. Targeting of food aid in rural Ethiopia: chronic need or inertia? Journal of Development Economics. 68(2): 247288.

Lerman, Robert I., and Shlomo Yitzhaki. 1985. Income inequality effects by income source: A new approach and applications to the United States. Review of Economics and Statistics 67(1):151-156.

Li, Jia, and Lucy Emerton. 2012. Moving closer to nature: Lessons for landscapes and livelihoods from the Miyun landscape, China. Gland, Switzerland: IUCN.

Lin, Justin Yifu. 1992. Rural Reforms and Agricultural Growth in China. American Economic Review. 82(1):34-51.

Meng, Lingsheng. 2013. Evaluating China's poverty alleviation program: A regression discontinuity approach. Journal of Public Economics. 101:1-11.

National Bureau of Statistics (NBS). 1991, 2012. China Statistical Yearbook. Beijing: China Statistics Press.

National Bureau of Statistics (NBS). 2009. China Yearbook of Rural Household Survey 2008. Beijing: China Statistics Press.

National Bureau of Statistics (NBS). 2013. Statistical Communiqué of the People's Republic of China on the 2012 National Economic and Social Development. http://www.stats.gov.cn/enGliSH/NewsEvents/201302/t20130222_26962.html Olinto, Pedro, Kathleen Beegle, Carlos Sobrado, and Hiroki Uematsu. 2013. The State of the Poor: Where Are The Poor, Where Is Extreme Poverty Harder to End, and What Is the Current Profile of the World's Poor. Economic Premise no. 125. Washington, DC: the World Bank.

Organisation for Economic Co-operation and Development (OECD). 2009. OECD Rural Policy Reviews: China 2009. Paris: OECD Publishing. doi: 10.1787/9789264059573-en. 
Park, Albert, Sangui Wang, and Guobao Wu. 2002. Regional poverty targeting in China. Journal of Public Economics. 86(1):123-153,

Ravallion, Martin, and Shaohua Chen. 2007. China's (Uneven) Progress against Poverty. Journal of Development Economics. 82(1):1-42.

Taylor, J. Edward, Jorge Mora, Richard Adams, and Alejandro Lopez-Feldman. 2005.

Remittances, Inequality and Poverty: Evidence from Rural Mexico. Agriculture and Resource Economics Working Papers no. 05-003. Davis: University of California, Davis.

Stark, Oded, J. Edward Taylor, and Shlomo Yitzhaki. 1986. Remittances and Inequality. The Economic Journal. 96(383):722-740.

Weitzman, Martin and Chenggang Xu. 1994. Chinese Township Village Enterprises as Vaguely Defined Cooperatives. Journal of Comparative Economics. 18(2):121-45.

Xinhua News Agency. 2014. No.1 Central Document targets rural reform. China Daily. January 19. http://www.chinadaily.com.cn/china/2014-01/19/content_17244268.htm. Accessed February 14, 2014.

Yin Runsheng, Guiping Yin, and Lanying Li. 2010. Assessing China’s Ecological Restoration Programs: What's Been Done and What Remains to Be Done? Environmental Management. 45(3):442-453. 
Table 1 - Major steps in China's antipoverty strategy

\begin{tabular}{|l|l|}
\hline Year/Period & Policies \\
\hline $1978-1985$ & Rural reforms (e.g. household responsibility system, increased agricultural prices). \\
\hline 1986 & Nationwide poverty alleviation strategy (incl. designated poor counties). \\
Establishment of the Leading Group for Economic Development in Poor Areas. \\
\hline 1993 & Establishment of the State Council Leading Group of Poverty Alleviation and Development. \\
\hline $1994-2000$ & $8-7$ Plan. \\
\hline 2000 & Sloping land conversion program. \\
\hline $2001-2010$ & New Century Rural Poverty Alleviation Plan. \\
\hline $2000-2002$ & Progressive implementation of the Tax-for-fee reform. \\
\hline $2003-2008$ & Implementation of the New Rural Cooperative Medical Insurance Scheme. Pilot in 4 provinces \\
& in 2003, extended to almost all rural counties by 2008. \\
\hline $2004-2007$ & Progressive implementation of the rural Minimum Income Guarantee program (dibao). \\
\hline 2006 & Complete elimination of all agricultural-related taxes. \\
\hline 2006 & New Socialist Countryside approved as government policy. \\
\hline 2007 & Free compulsory education in all rural areas. \\
\hline 2011 & Outline of Poverty Reduction and Development of China's Rural Areas (2011-2020). \\
\hline
\end{tabular}


Table 2 - Program participation and income sources differences across villages

\begin{tabular}{|c|c|c|c|c|c|c|c|c|c|c|}
\hline Villages: & Dadianzi & Zhongyushudian & Labagoumen & Sidaoxue & Xiahebei & Dongcha & Maoshan & Huying & Sunzhazi & Miaoying \\
\hline $\begin{array}{l}\text { Location (main } \\
\mathrm{road} / \mathrm{secondary} \mathrm{road} / \text { remote) }\end{array}$ & Main road & Sec. road & Main road & Main road & Sec. road & Remote & Main road & Remote & Sec. road & Remote \\
\hline $\begin{array}{l}\text { Share of program } \\
\text { participating households }\end{array}$ & $89.3 \%$ & $16.7 \%$ & $68.6 \%$ & $83.3 \%$ & $46.4 \%$ & $91.4 \%$ & $91.4 \%$ & $83.3 \%$ & $75.8 \%$ & $83.9 \%$ \\
\hline $\begin{array}{l}\text { Per capita annual income } \\
\text { (yuan) }\end{array}$ & 5,469 & 4,495 & 4,171 & 6,371 & 5,049 & 6,430 & 6,360 & 4,560 & 9,397 & 5,616 \\
\hline \multicolumn{11}{|c|}{ Income source share in total income } \\
\hline Farm income & $37.0 \%$ & $36.5 \%$ & $22.5 \%$ & $21.5 \%$ & $14.5 \%$ & $14.0 \%$ & $12.7 \%$ & $9.5 \%$ & $5.6 \%$ & $2.3 \%$ \\
\hline Off-farm income & $42.8 \%$ & $39.4 \%$ & $48.3 \%$ & $72.3 \%$ & $77.1 \%$ & $73.5 \%$ & $74.2 \%$ & $72.1 \%$ & $78.1 \%$ & $76.9 \%$ \\
\hline Forest warden wage work & $16.5 \%$ & $7.1 \%$ & $15.8 \%$ & $46.2 \%$ & $30.1 \%$ & $45.7 \%$ & $47.0 \%$ & $55.0 \%$ & $30.7 \%$ & $52.0 \%$ \\
\hline Remittances & $12.6 \%$ & $11.8 \%$ & $23.7 \%$ & $17.1 \%$ & $20.0 \%$ & $18.1 \%$ & $16.0 \%$ & $6.5 \%$ & $21.5 \%$ & $4.2 \%$ \\
\hline Other wage work & $8.3 \%$ & $11.6 \%$ & $5.3 \%$ & $7.3 \%$ & $8.3 \%$ & $5.6 \%$ & $9.7 \%$ & $7.2 \%$ & $6.3 \%$ & $9.8 \%$ \\
\hline Self-employment & $3.6 \%$ & $7.1 \%$ & $3.4 \%$ & $1.7 \%$ & $5.6 \%$ & $0.6 \%$ & $1.5 \%$ & $1.1 \%$ & $2.9 \%$ & $8.2 \%$ \\
\hline $\begin{array}{l}\text { Family non-agricultural } \\
\text { activities }\end{array}$ & $1.9 \%$ & $1.7 \%$ & $0.2 \%$ & $0.0 \%$ & $13.2 \%$ & $3.5 \%$ & $0.0 \%$ & $2.3 \%$ & $16.7 \%$ & $2.7 \%$ \\
\hline Other income & $20.2 \%$ & $24.1 \%$ & $29.1 \%$ & $6.2 \%$ & $8.4 \%$ & $12.5 \%$ & $13.1 \%$ & $18.4 \%$ & $16.3 \%$ & $20.7 \%$ \\
\hline Subsidies & $16.9 \%$ & $17.6 \%$ & $19.4 \%$ & $4.9 \%$ & $8.4 \%$ & $9.2 \%$ & $8.2 \%$ & $16.9 \%$ & $10.3 \%$ & $15.6 \%$ \\
\hline Other (pension, rent, etc.) & $3.3 \%$ & $6.5 \%$ & $9.7 \%$ & $1.3 \%$ & $0.0 \%$ & $3.3 \%$ & $4.9 \%$ & $1.6 \%$ & $6.0 \%$ & $5.1 \%$ \\
\hline \# surveyed households & 28 & 36 & 35 & 30 & 28 & 35 & 35 & 30 & 33 & 31 \\
\hline
\end{tabular}

Source: Labagoumen rural household survey 2009. 
Table 3 - Sample average for participating and non-participating households

\begin{tabular}{|c|c|c|c|c|}
\hline & Total & $\begin{array}{c}\text { Non- } \\
\text { participating }\end{array}$ & Participating & $\begin{array}{c}\text { Difference in } \\
\text { means } \\
\text { (significance } \\
\text { level) }\end{array}$ \\
\hline Age of household head & 53.35 & 56.91 & 52.00 & $-4,91^{* * *}$ \\
\hline Average household health & 2.119 & 1.965 & 2.177 & $0,212^{* *}$ \\
\hline Minority member & 0.620 & 0.636 & 0.614 & $-0,022(\mathrm{NS})$ \\
\hline Political cadre member & 0.343 & 0.375 & 0.330 & $-0,045(\mathrm{NS})$ \\
\hline \multicolumn{5}{|c|}{ Household composition and labour force } \\
\hline Household size & 3.299 & 3.102 & 3.373 & $0,271^{* *}$ \\
\hline$\#$ active members & 2.121 & 1.750 & 2.262 & $0,512^{* * *}$ \\
\hline \# elderly & 0.455 & 0.682 & 0.369 & $-0,313^{* * *}$ \\
\hline \# children below 7 & 0.184 & 0.136 & 0.202 & $0,066^{*}$ \\
\hline SLCP participant & 0.604 & 0.500 & 0.644 & $0,144^{* * *}$ \\
\hline Household with migrants & 0.290 & 0.284 & 0.292 & 0,008 (NS) \\
\hline \multicolumn{5}{|l|}{ Household assets } \\
\hline Arable land per adult & 1.867 & 1.702 & 1.929 & $0,227(\mathrm{NS})$ \\
\hline House equipped with bathroom & 0.255 & 0.295 & 0.240 & $-0,055(\mathrm{NS})$ \\
\hline \# Observations & 321 & 88 & 233 & \\
\hline
\end{tabular}

Source: Labagoumen rural household survey 2009.

Notes: The mean test column indicates the significance level of mean differences between participating and nonparticipating households. NS: non-significant. ${ }^{*}$ Significant at 10 percent. ${ }^{* *}$ Significant at 5 percent.

Significant at 1 percent. Some averages are calculated over a smaller number of observations because of missing values. We only report the total number for reference. 
Table 4 - Probit estimates on households' program participation

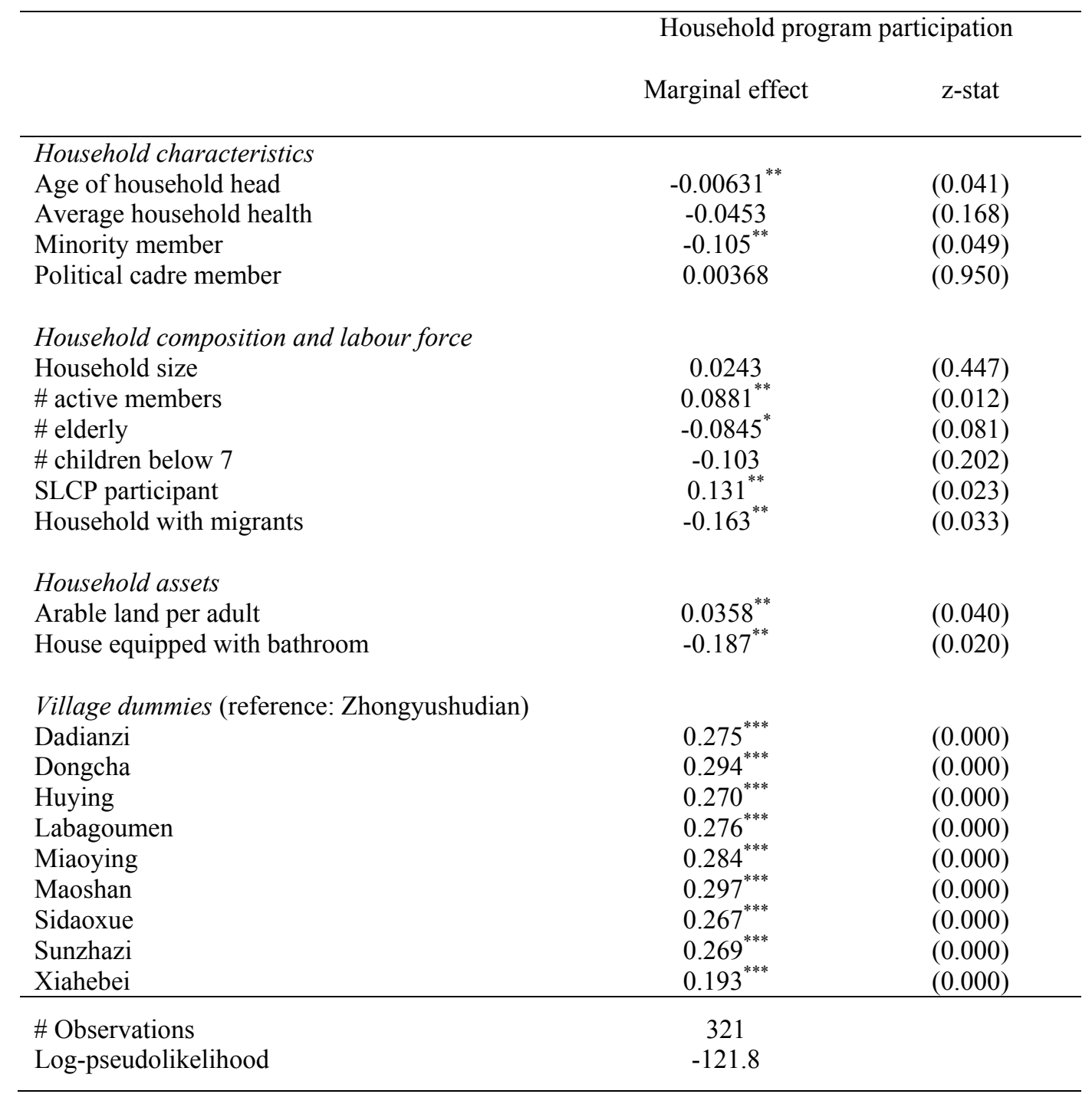

Source: Labagoumen rural household survey 2009.

Notes: Marginal effects are reported in the table. They measure the change in the probability of participating from a unit change in the explanatory variable. ${ }^{*}$ Significant at 10 percent. ${ }^{* *}$ Significant at 5 percent. ${ }^{* * *}$ Significant at 1 percent. Robust standard errors. 
Table 5 - Individual occupation distribution

\begin{tabular}{ccccccc}
\hline & Forest warden & Farmer & Local off-farm & Migrant & No occupation & Total \\
\hline Number & 404 & 544 & 98 & 126 & 172 & 875 \\
\% of total & $46.2 \%$ & $62.2 \%$ & $11.2 \%$ & $14.4 \%$ & $19.7 \%$ & \\
\hline
\end{tabular}

Source: Labagoumen rural household survey 2009.

Note: sample reduced to individuals aged between 16 and 75 .

Table 6 - Correlation across occupations

\begin{tabular}{lcccc}
\hline & Farming & Forest warden & Local off-farm & Migrant \\
\hline Farming & 1.000 & & & \\
Forest warden & 0.585 & 1.000 & & \\
& $(0.000)$ & & & \\
Local off-farm & 0.190 & 0.041 & 1.000 & \\
& $(0.000)$ & $(0.182)$ & & \\
Migrant & -0.271 & -0.226 & -0.107 & 1.000 \\
& $(0.000)$ & $(0.000)$ & $(0.000)$ & \\
\hline
\end{tabular}

Source: Labagoumen rural household survey 2009.

Note: sample reduced to individuals aged between 16 and 76. The significance level is given in parenthesis. 
Table 7 - Multinomial logit estimates on individual program participation

\begin{tabular}{|c|c|c|c|c|}
\hline & Mean value & $\begin{array}{l}\text { Farming and forest } \\
\text { warden }\end{array}$ & Farming only & $\begin{array}{c}\text { Forest warden } \\
\text { only }\end{array}$ \\
\hline \multicolumn{5}{|l|}{ Individual characteristics } \\
\hline Gender $($ male $=1)$ & 0.498 & $\begin{array}{c}1.332 \\
(0.273)\end{array}$ & $\begin{array}{l}1.746^{* *} \\
(0.397)\end{array}$ & $\begin{array}{l}0.437^{* *} \\
(0.183)\end{array}$ \\
\hline Age & 44.40 & $\begin{array}{l}2.122^{* * *} \\
(0.164)\end{array}$ & $\begin{array}{l}1.718^{* * *} \\
(0.133)\end{array}$ & $\begin{array}{l}1.243^{* *} \\
(0.109)\end{array}$ \\
\hline Age squared & 2212.7 & $\begin{array}{l}0.993^{* * *} \\
(0.001)\end{array}$ & $\begin{array}{l}0.995^{* * *} \\
(0.001)\end{array}$ & $\begin{array}{l}0.998^{*} \\
(0.001)\end{array}$ \\
\hline Years of education & 7.427 & $\begin{array}{l}0.901^{* *} \\
(0.038)\end{array}$ & $\begin{array}{l}0.879^{* * *} \\
(0.040)\end{array}$ & $\begin{array}{l}1.020 \\
(0.079)\end{array}$ \\
\hline Health status & 2.210 & $\begin{array}{l}1.653^{* * *} \\
(0.191)\end{array}$ & $\begin{array}{l}1.641^{* * *} \\
(0.183)\end{array}$ & $\begin{array}{c}1.056 \\
(0.243)\end{array}$ \\
\hline Minority & 0.497 & $\begin{array}{c}0.972 \\
(0.241)\end{array}$ & $\begin{array}{l}1.776^{* *} \\
(0.506)\end{array}$ & $\begin{array}{c}0.531 \\
(0.249)\end{array}$ \\
\hline Party or committee member & 0.128 & $\begin{array}{c}1.074 \\
(0.384)\end{array}$ & $\begin{array}{l}2.294^{* *} \\
(0.858)\end{array}$ & $\begin{array}{c}0.563 \\
(0.437)\end{array}$ \\
\hline $\begin{array}{l}\text { Household composition } \\
\text { and labour force }\end{array}$ & & & & \\
\hline Household size & 3.697 & $\begin{array}{l}0.600^{* * *} \\
(0.095)\end{array}$ & $\begin{array}{l}0.588^{* * *} \\
(0.101)\end{array}$ & $\begin{array}{c}0.649 \\
(0.182)\end{array}$ \\
\hline$\#$ active members & 2.400 & $\begin{array}{l}1.890^{* * *} \\
(0.351)\end{array}$ & $\begin{array}{l}1.692^{* * *} \\
(0.260)\end{array}$ & $\begin{array}{c}1.176 \\
(0.370)\end{array}$ \\
\hline \# elderly & 0.374 & $\begin{array}{c}0.990 \\
(0.254)\end{array}$ & $\begin{array}{c}1.248 \\
(0.341)\end{array}$ & $\begin{array}{c}0.700 \\
(0.276)\end{array}$ \\
\hline \# children below 7 & 0.217 & $\begin{array}{l}2.478^{* *} \\
(0.987)\end{array}$ & $\begin{array}{l}2.716^{* *} \\
(1.177)\end{array}$ & $\begin{array}{c}2.409 \\
(1.756)\end{array}$ \\
\hline Household assets & & & & \\
\hline Arable land per adult & 1.788 & $\begin{array}{l}1.690^{* * *} \\
(0.231)\end{array}$ & $\begin{array}{l}1.470^{* * *} \\
(0.216)\end{array}$ & $\begin{array}{l}0.523^{*} \\
(0.191)\end{array}$ \\
\hline SLCP participant & 0.636 & $\begin{array}{c}1.758 \\
(0.626)\end{array}$ & $\begin{array}{c}1.352 \\
(0.421)\end{array}$ & $\begin{array}{l}0.481^{*} \\
(0.197)\end{array}$ \\
\hline Household with migrants & 0.358 & $\begin{array}{l}0.419^{* * *} \\
(0.137)\end{array}$ & $\begin{array}{c}0.793 \\
(0.255)\end{array}$ & $\begin{array}{c}0.942 \\
(0.616)\end{array}$ \\
\hline House equipped with bathroom & 0.285 & $\begin{array}{l}0.465^{* *} \\
(0.162)\end{array}$ & $\begin{array}{c}1.309 \\
(0.493) \\
\end{array}$ & $\begin{array}{c}0.652 \\
(0.330) \\
\end{array}$ \\
\hline \# Observations & 871 & 362 & 181 & 35 \\
\hline
\end{tabular}

Source: Labagoumen rural household survey 2009.

Notes: The choice comparison is any occupation other than farming and/or forest warden job. The relative risk ratio for a one unit change in a variable is the exponential value of the corresponding coefficient $(\exp (b) \operatorname{rather}$ than b). Standard errors and confidence intervals are similarly transformed. Individual decisions are not assumed to be independent across members of a given household. Standard errors are adjusted for clustering by households (315 households). Log-pseudolikelihood $=-630.084$. Pseudo- $\mathrm{R}^{2}=0.39$. Village dummies are also included in the estimation (not reported in the table). ${ }^{*}$ Significant at 10 percent. ${ }^{* *}$ Significant at 5 percent. ${ }^{* * *}$ Significant at 1 percent. 
Table 8 - Household income by source, 2008

\begin{tabular}{|c|c|c|c|c|c|c|c|c|}
\hline & \multicolumn{5}{|c|}{ Household income in 2008} & \multicolumn{3}{|c|}{ Comparison with income sources in 2003} \\
\hline & Mean & $\begin{array}{l}\text { Standard } \\
\text { deviation }\end{array}$ & $\begin{array}{l}\text { Share in total } \\
\text { income }\end{array}$ & $\begin{array}{l}\text { \% of households } \\
\text { with income } \\
\text { from the source }\end{array}$ & $\begin{array}{c}\text { Mean among } \\
\text { households with } \\
\text { income from } \\
\text { that source }\end{array}$ & Mean & $\begin{array}{c}\text { Share in } \\
\text { total income }\end{array}$ & $\begin{array}{l}\% \text { of households } \\
\text { with income } \\
\text { from the source }\end{array}$ \\
\hline Total income (in yuan) & 18,439 & 17,735 & & & & 6,015 & & \\
\hline Per capita income & 5,633 & 4,311 & & & & 1,935 & & \\
\hline Farm income & 2,838 & 7,164 & $17.6 \%$ & $69 \%$ & 4,141 & 1,645 & $36.7 \%$ & $58 \%$ \\
\hline off-farm income & 13,662 & 15,858 & $65.2 \%$ & $88 \%$ & 15,552 & 3,434 & $44.3 \%$ & $52 \%$ \\
\hline $\begin{array}{l}\text { From family non- } \\
\text { agricultural activities }\end{array}$ & 1,205 & 5,716 & $4.1 \%$ & $12 \%$ & 9,668 & & & \\
\hline Remittances & 4,261 & 9,231 & $15.1 \%$ & $29 \%$ & 14,708 & 718 & $7.6 \%$ & $12 \%$ \\
\hline Forest warden wage work & 4,739 & 4,262 & $34.4 \%$ & $73 \%$ & 6,528 & & & \\
\hline Other wage work & 2,484 & 10,807 & $7.9 \%$ & $18 \%$ & 13,746 & & & \\
\hline Self-employment & 974 & 4,290 & $3.5 \%$ & $9 \%$ & 11,166 & & & \\
\hline Other income & 1,939 & 3,718 & $17.1 \%$ & $68 \%$ & 2,841 & 936 & $19 \%$ & $27 \%$ \\
\hline Subsidies & 1,206 & 1,943 & $12.8 \%$ & $62 \%$ & 1,936 & & & \\
\hline Other (pension, rent, etc.) & 732 & 3,104 & $4.3 \%$ & $15 \%$ & 4,896 & & & \\
\hline
\end{tabular}

Source: Labagoumen rural household survey 2009 and 2003.

Notes: Income sources in 2008 and in 2003 are not fully comparable since some categories were not defined in 2003 . The numbers reported in the last three columns are those that are consistently comparable with data for the year 2008 . 
Table 9 - Gini decomposition by income source, 2008

\begin{tabular}{|c|c|c|c|c|c|}
\hline Income source & $\begin{array}{c}\text { Income } \\
\text { share }\left(S_{k}\right)\end{array}$ & $\begin{array}{l}\text { Source Gini } \\
\qquad\left(G_{k}\right)\end{array}$ & $\begin{array}{c}\text { Correlation with } \\
\text { rank of total } \\
\text { income }\left(\boldsymbol{R}_{k}\right) \\
\end{array}$ & $\begin{array}{c}\text { Share of } \\
\text { income } \\
\text { inequality }\end{array}$ & Marginal effect \\
\hline Farm income & 0.1539 & 0.6981 & 0.4818 & 0.1226 & -0.0313 \\
\hline $\begin{array}{l}\text { Family non- } \\
\text { agricultural income }\end{array}$ & 0.0653 & 0.9448 & 0.7217 & 0.1055 & 0.0401 \\
\hline Remittances & 0.2311 & 0.8347 & 0.8040 & 0.3672 & 0.1361 \\
\hline Forest warden wage & 0.2570 & 0.4968 & 0.2748 & 0.0831 & -0.1739 \\
\hline Other wage work & 0.1347 & 0.9187 & 0.7572 & 0.2219 & 0.0872 \\
\hline Self-employment & 0.0528 & 0.9531 & 0.6638 & 0.0791 & 0.0263 \\
\hline Subsidies & 0.0654 & 0.7342 & -0.0959 & -0.0109 & -0.0763 \\
\hline $\begin{array}{l}\text { Other income } \\
\text { (pension, rent, etc.) }\end{array}$ & 0.0397 & 0.9366 & 0.3588 & 0.0316 & -0.0081 \\
\hline
\end{tabular}

Source: Labagoumen rural household survey 2009.

Notes: $N=321$ households. Total income Gini coefficient $G=0.4223$. Note that the high level of Gini coefficients by source of income can be partly attributed to the fact that they include zeros for some households. The marginal effect (last column) measures the percentage change in the Gini from a 10 percent change in income source. 
Table 10 - Gini decomposition by income source for villages with important agricultural income

\begin{tabular}{lccccc}
\hline Income source & $\begin{array}{c}\text { Income } \\
\text { share }\left(\boldsymbol{S}_{\boldsymbol{k}}\right)\end{array}$ & $\begin{array}{c}\text { Source Gini } \\
\left(\boldsymbol{G}_{\boldsymbol{k}}\right)\end{array}$ & $\begin{array}{c}\text { Correlation with } \\
\text { rank of total } \\
\text { income }\left(\boldsymbol{R}_{\boldsymbol{k}}\right)\end{array}$ & $\begin{array}{c}\text { Share of } \\
\text { income } \\
\text { inequality }\end{array}$ & Marginal effect \\
\hline Farm income & 0.2673 & 0.6038 & 0.5389 & 0.1962 & -0.0711 \\
Family non- & 0.0132 & 0.9521 & 0.4608 & 0.0131 & -0.0001 \\
$\begin{array}{l}\text { agricultural income } \\
\text { Remittances }\end{array}$ & 0.2709 & 0.8440 & 0.8072 & 0.4163 & 0.1454 \\
Forest warden wage & 0.0840 & 0.6470 & 0.1090 & 0.0134 & -0.0706 \\
$\begin{array}{l}\text { Other wage work } \\
\text { Self-employment }\end{array}$ & 0.1076 & 0.8841 & 0.6274 & 0.1346 & 0.0270 \\
Subsidies & 0.1020 & 0.9474 & 0.8387 & 0.1828 & 0.0808 \\
$\begin{array}{l}\text { Other income } \\
\text { (pension, rent, etc.) }\end{array}$ & 0.0897 & 0.7133 & -0.1529 & -0.0221 & -0.1117 \\
\hline Source: Labagoun & 0.0654 & 0.9176 & 0.4856 & 0.0657 & 0.0003 \\
\hline
\end{tabular}

Source: Labagoumen rural household survey 2009.

Notes: See Table 9. Total income Gini coefficient $G=0.4433$. The villages included in this decomposition are

Dadianzi, Zhongyushudian and Labagoumen.

Table 11 - Gini decomposition by income source for villages with small agricultural income

\begin{tabular}{lccccc}
\hline Income source & $\begin{array}{c}\text { Income } \\
\text { share }\left(\boldsymbol{S}_{\boldsymbol{k}}\right)\end{array}$ & $\begin{array}{c}\text { Source Gini } \\
\left(\boldsymbol{G}_{\boldsymbol{k}}\right)\end{array}$ & $\begin{array}{c}\text { Correlation with } \\
\text { rank of total } \\
\text { income }\left(\boldsymbol{R}_{\boldsymbol{k}}\right)\end{array}$ & $\begin{array}{c}\text { Share of } \\
\text { income } \\
\text { inequality }\end{array}$ & Marginal effect \\
\hline $\begin{array}{l}\text { Farm income } \\
\text { Family non- }\end{array}$ & 0.1154 & 0.7332 & 0.5667 & 0.1177 & 0.0023 \\
agricultural income & 0.0830 & 0.9305 & 0.7227 & 0.1370 & 0.0540 \\
Remittances & 0.2176 & 0.8298 & 0.8107 & 0.3592 & 0.1416 \\
Forest warden wage & 0.3158 & 0.3604 & 0.2262 & 0.0632 & -0.2526 \\
Other wage work & 0.1439 & 0.9251 & 0.7931 & 0.2591 & 0.1152 \\
Self-employment & 0.0361 & 0.9475 & 0.5359 & 0.0450 & 0.0089 \\
Subsidies & 0.0572 & 0.7418 & -0.0371 & -0.0039 & -0.0611 \\
Other income & & & & & -0.0083 \\
(pension, rent, etc.) & 0.0310 & 0.9426 & 0.3159 & 0.0226 & -0.0083 \\
\hline
\end{tabular}

Source: Labagoumen rural household survey 2009.

Notes: See Table 9. Total income Gini coefficient $G=0.4075$. The villages included in this decomposition are

Sidaoxue, Xiahebei, Dongcha, Maoshan, Huying, Sunzhazi and Miaoying. 
Figure 1 - Age distribution by occupation (Kernel density)

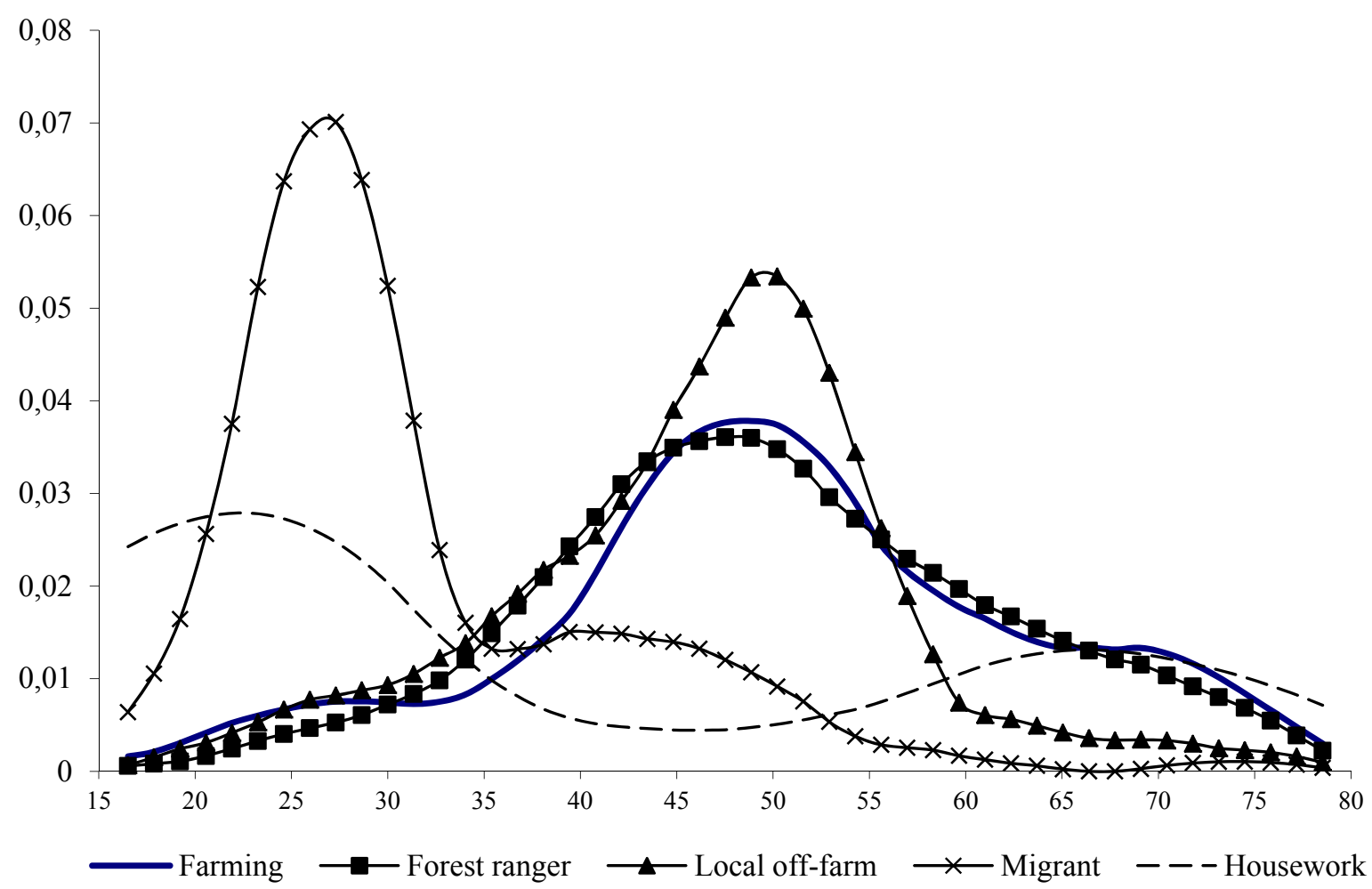

Source: Labagoumen rural household survey 2009. 